\title{
Improving Infiltration of Irrigated Mediterranean Soils with Polyacrylamide
}

\author{
Francisco L. Santos; Ricardo P. Serralheiro \\ Department of Rural Engineering, University of Évora, Évora, Portugal; e-mail of corresponding author: fls@uevora.pt
}

(Received 26 May 1999; accepted in revised form 11 February 2000)

\begin{abstract}
The effects of continuous $(1.0 \mathrm{mg} / l)$ and concentrated $(10 \mathrm{mg} / l)$ irrigation water-added polyacrylamide (PAM) on infiltration of a highly erodible Mediterranean soil were studied using recirculating furrow infiltrometers. Polyacrylamide avoided the seal formation observed in the wetted surface of the control furrow and helped to maintain higher infiltration rates for both PAM treatments. Mean final cumulative infiltration for the continuous and concentrated PAM experiments increased by 20 and 14\%, respectively, as the result of reduced seal formation and surface sealing. Steady-state furrow infiltration rates, evaluated with disc infiltrometers $15 \mathrm{~h}$ after irrigation and under soil water tensions of 40 and $100 \mathrm{~mm}$, confirmed the infiltration benefit of PAM treatments. Unsaturated hydraulic conductivity calculated under the same tensions revealed that the PAMtreated furrows were about $95 \%$ more permeable than the control. Polyacrylamide application also increased average saturated conductivity by $168 \%$ because of more unblocked pores in the treated furrows. The ability of PAM to influence surface soil conditions and improve infiltration can greatly enhance management of irrigated Mediterranean soils by allowing longer irrigation and higher inflow rates. Application of $10 \mathrm{mg} / \mathrm{l}$ in the inflow only during the advance phase of the irrigation can reduce labour, and ensures that loss of PAM from furrow tail water is minimized and that quantities applied during the season are reduced.
\end{abstract}

(C) 2000 Silsoe Research Institute

\section{Introduction}

Of the 870000 irrigated hectares in Portugal, $85 \%$ is under surface irrigation and primarily furrow-irrigated (74\% of the total irrigated area) (Raposo, 1997). In the south, a large irrigation scheme is currently under construction (Alqueva's project) that will add a further 110000 irrigated hectares by the end of year 2025. This area currently consists of highly erodible and low-permeable Mediterranean soils.

Mediterranean soils are very typical of the irrigation districts in southern Portugal, where they represent $40 \%$ of all soils. The particular characteristic of the Mediterranean soils is a rapidly permeable A-horizon overlaying a B-horizon of very low permeability. If the wetting front under irrigation encounters this zone of low permeability, it significantly reduces infiltration and the soil infiltration rate becomes limited to the low permeability of this B-horizon (Serralheiro, 1995). Due to the soil conditions at the surface (texture, structure and low aggregate stability), however, this often happens late in irrigation. With the first irrigation, the advance stream rapidly induces sediment detachment and movement at the soil surface, causing soil pore blockage along the freshly prepared furrows, and surface crusting (Santos et al., 1998). Infiltration rates are thereafter significantly reduced. The main consequence of this soil infiltration behaviour is an almost constant advance velocity along the furrow in the subsequent irrigation events (Serralheiro, 1995; Santos et al., 1998) and, consequently, a high potential for the advance stream to induce more soil erosion, sediment loss and runoff. Under these conditions, crop water requirements are met with shorter irrigation periods at higher (but less than economical) irrigation frequencies. Consequently, best management irrigation practices for these soils always recommend short irrigation periods, low initial inflow rates and conservation practices to control erosion and increase infiltration.

\subsection{Erosion control with water-added polyacrylamide application}

According to Sojka and Lentz (1996), polyacrylamide treatment of irrigation water may be the fastest growing 
conservation technology in irrigated agriculture in the USA. Use of PAM is highly effective in reducing erosion below the soil loss tolerance limits on furrow slopes ranging from $0 \cdot 5-3 \cdot 5 \%$. Sojka and Lentz (1997) also reported that the technology is being well received by furrow irrigators. Work published by other authors (McCuthan et al., 1993; Ben-Hur, 1994; USDA NRCS, 1995) also concluded that the application of PAM is an excellent amendment to reduce sediment chemical loading in the runoff from irrigated fields. When added to the irrigation water, anionic water-soluble polyacrylamide (PAM) has been reported to increase soil aggregate stability, reduce sediment detachment and transport, flocculate suspended sediments and increase furrow infiltration (Lentz et al., 1992; Lentz and Sojka, 1994; Trout et al., 1995; Zhang \& Miller, 1996a, 1996b). Sojka et al. (1998) reported the elimination of $94 \%$ of furrow runoff soil loss and $15-50 \%$ increase in infiltration with seasonal PAM application of $3.5-8 \cdot 0 \mathrm{~kg} / \mathrm{ha}$. Polyacrylamide was used at a rate of $10 \mathrm{~g} / \mathrm{m}^{3}$ in the advancing flow. According to Sojka and Lentz (1997), PAM is a high molecular weight, large anionic, copolymer formulated to the same standards as that used for potable water treatment and for food processing and packaging. Containing no more than $0.05 \%$ monomer, which is not released by chemical decomposition, PAM application is an excellent, costeffective, and safe technology to reduce both sediment and chemical loading in agricultural runoff (Barvenik, 1994). Lentz and Sojka (1996), after years of field trials comparing various PAM application strategies to reduce erosion on a range of furrow lengths, slopes and inflows, concluded that the most effective PAM treatment is to concentrate application during the advance phase of the irrigation. The effectiveness of applying PAM at low rates was attributed to treatment of only the thin layer of soil immediately affected by the dispersion and sheer of the furrow stream.

\subsection{Infiltration control with water-added polyacrylamide application}

In addition to soil erosion control benefits, the use of anionic polyacrylamide in furrow irrigation has been shown to highly improve total furrow infiltrated volumes (Lentz \& Sojka, 1994; Ben-Hur, 1994; Trout et al., 1995; Sojka \& Lentz, 1996; Zhang \& Miller, 1996b). According to Sojka and Lentz (1997), divalent cations in water act as a bridge between the large, negatively charged PAM molecules and soil particles, increasing soil cohesion and strengthening aggregates at the furrow bottom. Sojka et al. (1998) reported that PAM at $10 \mathrm{~g} / \mathrm{m}^{3}(10 \mathrm{ppm})$ during water advance nearly eliminated detachment and transport of soil in furrows. They showed that soil par- ticles at the soil-water interface are bound together in the presence of PAM which, acting also as a settling agent, flocculates dispersed particles, allowing them to settle to the furrow bottom. Lentz and Sojka (1994) reported net infiltration increase of $15 \%$ on silt loam soil in field scale tests when furrows advance water was treated with up to $20 \mathrm{ppm}$ of PAM. Trout et al. (1995) using a recirculating infiltrometer also reported infiltration increase of $30 \%$ in the same soil. They also showed that infiltration was inversely related to maximum sediment concentration in the flow. McCutchan et al. (1993) reported 50\% infiltration increase on finer textured soils. The general claim is that the use of PAM reduced sediment deposition, prevented seal formation and pore blockage along the wetted perimeter and promoted infiltration and greater lateral flow in the irrigated furrows. Tension infiltrometry (Sojka et al., 1998) confirmed that PAM improves infiltration by maintaining pores open to the furrow surface.

It was hypothesized that the strategy of applying PAM to the furrow stream flow to achieve a concentration of 10 p.p.m. $\left(\mathrm{g} / \mathrm{m}^{3}\right)$ in the advancing water flow before runoff began, could increase aggregate stability of the Mediterranean soils, flocculate sediments and help to reduce erosion and maintain high infiltration rates. Santos et al. (1998) had previously reported erosion reduction of $87 \%$ on Mediterranean soils with continuous application of PAM during irrigation. Successful control of erosion and infiltration with application of PAM only during the advance phase of irrigation would ensure an alternative management of polyacrylamide in Mediterranean soils, minimizing quantities applied and furrow tail water losses. To test the suitability of the proposed strategy recirculating furrow infiltrometers were used. To assess the degree of surface seal formation and evaluate infiltration and water transmission through pores of specific diameter, tension infiltrometer steady-state infiltration rates and hydraulic conductivity tests were also carried out.

\subsection{Infiltrometers and disc infiltrometers in furrow irrigation}

The fundamental aspects of the use of infiltrometers to evaluate infiltration characteristics in an irrigation furrow have been covered elsewhere (Bondurant, 1957; Malano, 1982; Blair \& Trout, 1989; Testezlaf et al., 1987; Trout, 1990; Trout et al., 1995). The three most common types are (a) the ring infiltrometer, (b) the blocked furrow infiltrometer, and (c) the recirculating furrow infiltrometer. The advantage of the latter is the simulation of the actual overland flow conditions that occur in surface irrigation. The water is kept flowing within the furrow test section and, according to Trout et al. (1995), the 
system completely recycles all sediment that runs off the section back through the furrow section. For field tests trying to determine the effectiveness of irrigation waterapplied PAM in reducing erosion and in establishing the mechanisms through which PAM affects infiltration, this dynamic representation of the infiltration process is essential.

Several methods have been developed to evaluate the hydraulic properties of the soil porous media. Recently, the disc infiltrometer has become a popular device for determining in situ soil hydraulic properties such as the saturated and unsaturated hydraulic conductivity, sorptivity and the macropore capillary length (White \& Sully, 1987; Smettem \& Clothier, 1989; White et al., 1992; Hussen \& Warrick, 1993, 1995). Disc infiltrometer measures steady-state infiltration rates unaffected by changing water potential gradients within soil profile. Ross et al. (1996) and Sojka et al. (1998) suggest its use to assess the degree of seal surface sealing when comparing steady-state infiltration of PAM-treated and control furrows. The device maintains a constant tension within a circular interface at the soil surface, and water intake and transmission through pores of specific equivalent diameter are evaluated.

\section{Materials and methods}

Three infiltration experiments were carried out at the University of Évora, Portugal, in 1998, on a Mediterranean soil with a sandy loam A-horizon overlaying a clay loam B-horizon of low permeability (Serralheiro, 1995; Table 1). Recirculating furrow infiltrometers, similar in design to that of Malano (1982) were used in the field infiltration tests. The device had the following components: a $200 l$ supply tank, a water-level recorder, two galvanized metal sumps, a sump pump, a portable engine-driven electrical generator, and associated hoses, valves, fittings and electrical wires.

Treatment 1 was designed to test the effectiveness of the continuous application of PAM at a rate of $1 \mathrm{mg} / \mathrm{l}$, throughout irrigation. Treatment 2 was designed to test the effectiveness of the concentrated $10 \mathrm{mg} / \mathrm{l}$ application of PAM only during the advance phase of irrigation. Treatment 3 was used as control. All treatments were established on previously non-irrigated furrows in a fallow field that had been recently disked and roller harrowed. Furrows of $0.5 \%$ slope and $100 \mathrm{~m}$ in length were shaped on a row spacing of $0.75 \mathrm{~m}$ with a furrow-forming tool and $6 \mathrm{~m}$ long furrow sections were established along the furrow length. Irrigation water was applied from the recirculating infiltrometers and treated furrows were alternated with untreated ones. Downstream, a weir maintained near normal flow depth, and the decreasing $200 l$ supply tank water level was recorded and related to the infiltration rate in the furrow section. Inflow rate to the furrow section was $14 \mathrm{l} / \mathrm{min}$ for all tests and irrigation continued for $5 \mathrm{~h}$. The sump pump of the infiltrometer continually recycled the runoff and all the sediment in the run off from the furrow section, back to the upper end of the section. As pointed out by Trout (1995) the system mimics a long furrow. Given enough time, sediment concentration in the section reaches an equilibrium level equivalent to that expected to occur in steady state at the end of a long furrow. A set of three infiltrometers was operated simultaneously, with two infiltrometers on PAM-treated and one on control furrows. Each test was replicated five times on adjacent $6 \mathrm{~m}$ long furrow sections. For each experiment a Student's $t$-test was used to examine if mean difference in infiltration between the treated and untreated furrows was equal to zero.

In treatment 1, $200 \mathrm{mg}$ of Superfloc A-836 (CyTec Industries, Wayne, NJ), a high-molecular weight $(15 \mathrm{mg} / \mathrm{mol})$, medium-charged density (18\%) anionic PAM was dissolved in one of the $200 l$ supply tanks before the beginning of each irrigation. The PAM concentration in the irrigation remained at $1.0 \mathrm{mg} / \mathrm{l}$ throughout the process. In treatment 2, $20 l$ of a $10 \mathrm{mg} / \mathrm{l}$ solution of Superfloc A-836 containing $200 \mathrm{mg}$ of PAM was added to the $6 \mathrm{~m}$ furrow section at the beginning of the test. This volume of water was sufficient to complete advance throughout and infiltrate the entire furrow section length before the start of irrigation. Treatment 3 used irrigation water free of PAM.

Table 1

Soil particle size fraction for specific depths of the Mediterranean soil profile

Particle size fraction, \%

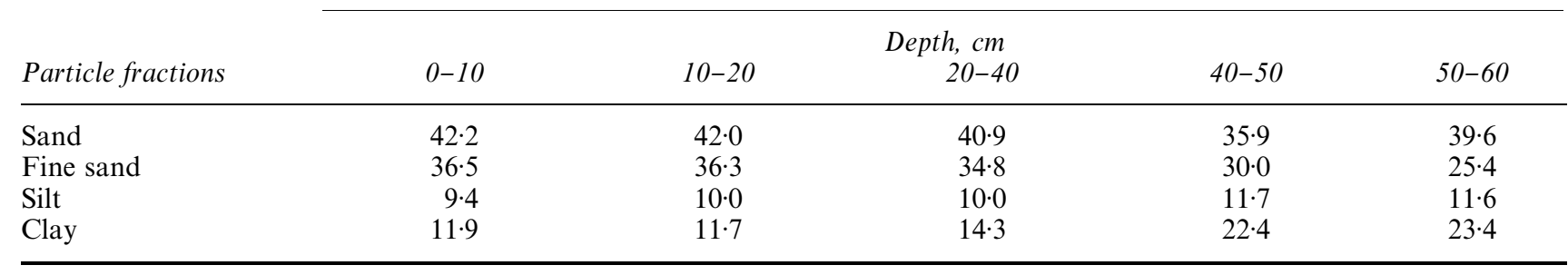


Disc infiltrometers of $10 \mathrm{~cm}$ in diameter and similar to the ones used by Sojka et al. (1998) and described by Cook et al. (1993) and Perroux and White (1988), were used to measure infiltration under soil water tensions of 40 and $100 \mathrm{~mm}$. Two tension replicates were taken $15 \mathrm{~h}$ after irrigation and at the mid-section of each treated and untreated furrow, adding up to a total of ten replicates per experiment and tension. The discs were placed on a bed of fine wet quartz sand contained in a $2 \mathrm{~cm}$ deep metal ring of $11.5 \mathrm{~cm}$ diameter, pushed $1-2 \mathrm{~cm}$ into the furrow bottom and, as soon as bubbles started to form in the infiltrometer bubble tower, time readings were taken. The readings were recorded each time the meniscus of the lowering water level in the tower reached a pre-determined depth mark. When the meniscus reached the last mark in the tower, the readings were stopped. Collected data were used as cumulative infiltration versus time.

The steady-state infiltration flow rates, $q$ in $\mathrm{mm} / \mathrm{min}$, were evaluated by plotting cumulative infiltration versus time and calculating the slope at large times. A procedure, described by Hussen and Warrick (1995) as multiple tension single disc, was used to evaluate the saturated and the unsaturated hydraulic conductivity, $K_{s}$ and $K_{w}$, respectively, in $\mathrm{mm} / \mathrm{h}$, corresponding to the two water supply potentials. The method assumes the Wooding (1968) solution for steady-state flow per unit area in the form

$$
q=K_{w}\left[1+\frac{4 \lambda_{c}}{\pi r_{o}}\right]
$$

where $r_{o}$ is the radius of the disc infiltrometer in $\mathrm{mm}$, and $\lambda_{c}$ is the macropore capillary length in $\mathrm{mm}$. Wooding assumed that the relation between unsaturated hydraulic conductivity satisfies the Gardner (1958) equation

$$
K_{w}=K_{s} \exp \left(\frac{h}{\lambda_{c}}\right)
$$

Table 2

Final cumulative infiltration for three treatments, control, $1 \cdot 0$ and $10 \mathrm{mg} / l$ polyacrylamide (PAM), measured for each irrigation test with blocked furrow infiltrometers

\begin{tabular}{|c|c|c|c|c|c|}
\hline \multirow[b]{2}{*}{ Test } & \multicolumn{5}{|c|}{ Cumulative infiltration, $l / m$} \\
\hline & Control & & $1.0 \mathrm{mg} / \mathrm{l} P A M$ & & $10 \mathrm{mg} / \mathrm{l} P A M$ \\
\hline 1 & $14 \cdot 9$ & & $17 \cdot 1$ & & $15 \cdot 3$ \\
\hline 2 & 16.8 & & $22 \cdot 2$ & & $15 \cdot 4$ \\
\hline 3 & $18 \cdot 1$ & & $24 \cdot 2$ & & $23 \cdot 9$ \\
\hline 4 & $17 \cdot 1$ & & $17 \cdot 2$ & & $21 \cdot 4$ \\
\hline 5 & $15 \cdot 7$ & & $19 \cdot 0$ & & $17 \cdot 4$ \\
\hline Avg & $16 \cdot 5$ & & $19 \cdot 9$ & & $18 \cdot 7$ \\
\hline S.D. & $1 \cdot 25$ & & $3 \cdot 15$ & & $3 \cdot 82$ \\
\hline$t$ Statistic & & $2 \cdot 9$ & & $0 \cdot 70$ & \\
\hline Prob $>t$ & & 0.034 & & 0.516 & \\
\hline
\end{tabular}

Cumulative infiltration, $l / m$

S.D., standard deviation.

where $h$ is the water supply potential in $\mathrm{mm}$. When Gardner's relationship is used, Wooding's equation is written as

$$
q=K_{s} \exp \left(\frac{h}{\lambda_{c}}\right)\left[1+\frac{4 \lambda_{c}}{\pi r_{o}}\right]
$$

With two different supply potentials, $h_{1}$ and $h_{2}$, and the corresponding $q$ values, the macropore capillary length is obtained by dividing two equations from Eqn (3), which results in

$$
\lambda_{c}=\frac{\left|h_{2}-h_{1}\right|}{\left|\ln \left(q_{2} / q_{1}\right)\right|}
$$

The value of $K_{s}$ is found by substituting $\lambda_{c}$ into Eqn (3). The values for $K_{w}$ at the water supply tensions are then obtained from Eqn (2).

\section{Results and discussion}

\subsection{Cumulative infiltration}

Using PAM in furrow irrigation water increased the average $5 \mathrm{~h}$ cumulative infiltration by 20 and $14 \%$, respectively, for the continuous and concentrated experiments (Table 2). The variability among PAM tests was larger than for the control, particularly on the ones applying PAM only in the advance furrow water. A1though the volume of water was sufficient to complete advance through the $6 \mathrm{~m}$ long furrow section, the rapid infiltration near the upper end section decreased the amount of PAM reaching downstream and might have induced variability in the coating and stabilization of the thin surface soil layer. Further dilution by subsequent irrigation might also have magnified the variability. Figure 1 depicts the cumulative infiltration variability over time for the repetitions carried out. Trout et al. (1995) and Lentz and Sojka (1994) had also reported high 

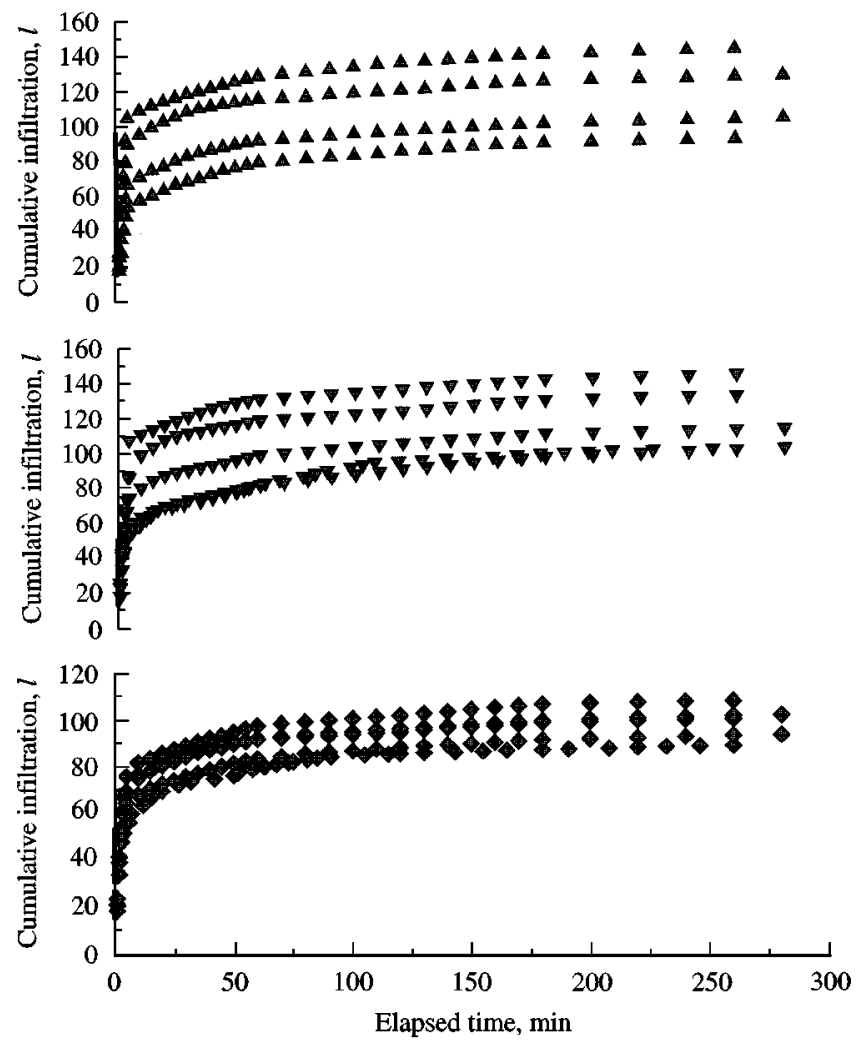

Fig. 1. Test of cumulative infiltration over time measured during irrigation with blocked furrow infiltrometers for three treatments: ๑, control; $\mathbf{\nabla}, 1.0 \mathrm{mg} / \mathrm{l}$ polyacrylamide (PAM); $\mathbf{\Delta}, 10 \mathrm{mg} / \mathrm{l}$ PAM

infiltration variability under furrow infiltrometer and field scale tests.

Regression lines of the data sets depicted in Fig. 1, and the corresponding coefficients of determination, are

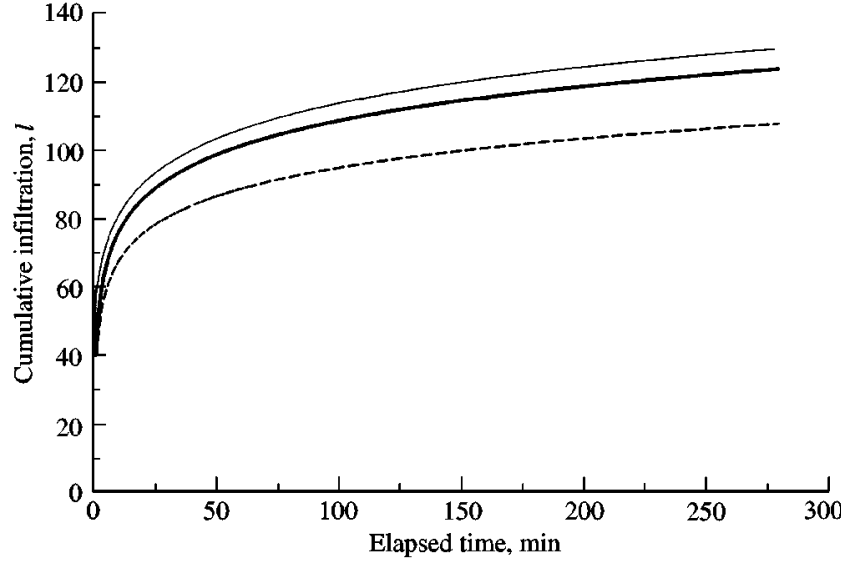

Fig. 2. Regression lines obtained from tests of cumulative infiltration over time —, $1.0 \mathrm{mg} / \mathrm{l}$, polyacrylamide (PAM), fitting equation $y=15 \cdot 1 \ln (x)+43 \cdot 5$, coefficient of determination $r^{2}=$ 0.604; —- $10 \mathrm{mg} / \mathrm{l}$ PAM, fitting equation $y=14 \cdot 1 \ln (x)+$ 43.2 and $r^{2}=0.532$; --.., control fitting equation $y=$ $11.9 \ln (x)+39.9$ and $r^{2}=0.854$

presented in Fig. 2. These show the higher effect of PAMadded water on infiltration. The curves also support the field perception that inconsistencies among PAM tests were small enough to allow for consistent PAM-treated average higher infiltration rates over time when compared to control. No evidence was found to support the claim of infiltration differences and benefit gains between the two PAM experiments.

\subsection{Steady-state infiltration rates}

Table 3 shows the average steady-state infiltration rates obtained for 40 and $100 \mathrm{~mm}$ tension for the five

Table 3

Average steady-state infiltration rates for three treatments, control, $1 \cdot 0$ and $10 \mathrm{mg} / l$ polyacrylamide (PAM) measured with tension infiltrometers under 40 and $100 \mathrm{~mm}$ tension and $15 \mathrm{~h}$ after the irrigation test

\begin{tabular}{|c|c|c|c|c|c|c|}
\hline \multirow[b]{4}{*}{ Test } & \multicolumn{6}{|c|}{ Infiltration rate, $\mathrm{mm} / \mathrm{min}$} \\
\hline & \multicolumn{2}{|c|}{ Control } & \multicolumn{2}{|c|}{$1.0 \mathrm{mg} / \mathrm{l} \mathrm{PAM}$} & \multicolumn{2}{|c|}{$10 \mathrm{mg} / \mathrm{l} P A M$} \\
\hline & \multicolumn{2}{|c|}{ Tension, mm } & \multicolumn{2}{|c|}{ Tension, $\mathrm{mm}$} & \multicolumn{2}{|c|}{ Tension, $\mathrm{mm}$} \\
\hline & 40 & 100 & 40 & 100 & 40 & 100 \\
\hline 1 & $25 \cdot 6$ & $19 \cdot 5$ & $46 \cdot 8$ & $45 \cdot 3$ & $23 \cdot 2$ & $24 \cdot 2$ \\
\hline 2 & $24 \cdot 5$ & $20 \cdot 2$ & $49 \cdot 7$ & $32 \cdot 0$ & $30 \cdot 6$ & $22 \cdot 1$ \\
\hline 3 & $21 \cdot 3$ & $17 \cdot 4$ & $31 \cdot 9$ & $48 \cdot 2$ & $32 \cdot 0$ & $18 \cdot 6$ \\
\hline 4 & $13 \cdot 3$ & $10 \cdot 9$ & $25 \cdot 8$ & $12 \cdot 7$ & $21 \cdot 0$ & $18 \cdot 6$ \\
\hline 5 & $12 \cdot 2$ & $10 \cdot 9$ & $29 \cdot 0$ & $12 \cdot 4$ & $33 \cdot 0$ & $17 \cdot 6$ \\
\hline Avg & $19 \cdot 4$ & $15 \cdot 8$ & $36 \cdot 6$ & $30 \cdot 1$ & $28 \cdot 0$ & $20 \cdot 2$ \\
\hline S.D. & $6 \cdot 3$ & $4 \cdot 6$ & $10 \cdot 9$ & $17 \cdot 1$ & $5 \cdot 5$ & $2 \cdot 8$ \\
\hline$t$ Statistic & \multicolumn{2}{|c|}{$3 \cdot 9$} & \multicolumn{2}{|c|}{$1 \cdot 0$} & \multicolumn{2}{|c|}{$2 \cdot 3$} \\
\hline Prob $>t$ & \multicolumn{2}{|c|}{$0 \cdot 01$} & \multicolumn{2}{|c|}{$0 \cdot 37$} & \multicolumn{2}{|c|}{$0 \cdot 07$} \\
\hline
\end{tabular}

S.D., standard deviation. 
Table 4

Statistics for the effects of polyacrylamide (PAM) and control treatment on soil steady-state infiltration rates under 40 and $100 \mathrm{~mm}$ tension

\begin{tabular}{lcc}
\hline & \multicolumn{2}{c}{ Prob $>t$ Statistic } \\
\cline { 2 - 3 } & \multicolumn{2}{c}{$\begin{array}{c}\text { Soil water tension, } m \\
40\end{array}$} \\
& & 100 \\
\hline Control by $1.0 \mathrm{mg} / l \mathrm{PAM}$ & 0.003 & 0.077 \\
Control by $10 \mathrm{mg} / l \mathrm{PAM}$ & 0.084 & 0.025 \\
$1.0 \mathrm{mg} / l \mathrm{PAM}$ by $10 \mathrm{mg} / l \mathrm{PAM}$ & 0.180 & 0.23 \\
\hline
\end{tabular}

tests of each treatment. Infiltration at $40 \mathrm{~mm}$ tension includes flow through pores less than $0.7 \mathrm{~mm}$ in diameter and at $100 \mathrm{~mm}$ tension flow through pores smaller than $0.30 \mathrm{~mm}$. Although there was some variability in the data from replicate pairs, for both tensions PAM-treated intake measurements, Tables 3 and 4, were significantly higher than control. No significant differences were observed between the two PAM treatments. The results corroborate the hypothesis that the lower infiltration observed on control tests are attributed to the continuous transport and deposition of sediments in the flowing water, which lead to pore blockage and the formation of a less-permeable surface seal. Segeren and Trout (1991) and Trout (1990) had shown that depositional seal formation resulting from erosion and sediment movement reduced furrow infiltration by $50 \%$ in silt loam soils. The same mechanism was also noticed in an irrigated Mediterranean soil by Santos et al. (1998). They indicated that the constant action of removal, transport and deposition of sediments affected the soil structure and particle size distribution at the surface, and the formation of surface seal and crusting. Table 5, adapted from their original data, shows the significant impact the process had on water intake rates and final cumulative infiltration of four consecutive irrigation events.

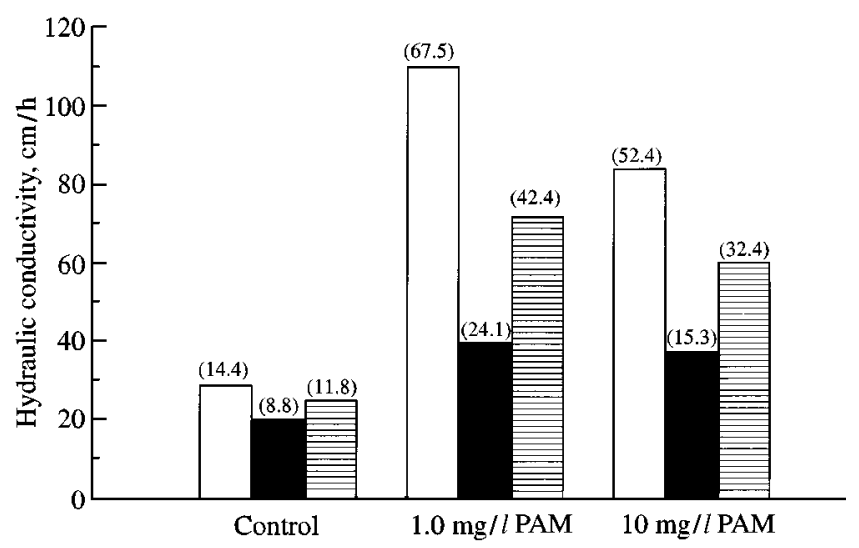

Fig. 3. Saturated hydraulic conductivity $K_{s}(\square)$ and average hydraulic conductivity estimates $K_{40}(\mathrm{E})$ and $K_{100}(\mathbf{\square})$ obtained from steady-state infiltration rates for three treatments (control, $1.0 \mathrm{mg} / \mathrm{l}$ polyacrylamide (PAM) and $10 \mathrm{mg} / \mathrm{l}$ PAM) measured $15 \mathrm{~h}$ after irrigation with tension infiltrometers under 40 and $100 \mathrm{~mm}$ tension. Standard deviation shown in parentheses

Figure 3 compares saturated and unsaturated hydraulic conductivities obtained from the average steady-state infiltration rates obtained in the furrows sections $15 \mathrm{~h}$ after irrigation. Saturated hydraulic conductivity differences, obtained in response to distinct surface sealing conditions, reveal that seal formed in the PAM-treated furrows are about $168 \%$ more permeable than the ones formed in non-treated furrows. As for the unsaturated hydraulic conductivity, Fig. 3 shows the same trend, with increases of 192 and $98 \%$ respectively, for the $1.0 \mathrm{mg} / \mathrm{l}$ PAM-treated furrows and 49 and $44 \%$ for the $10 \mathrm{mg} / \mathrm{l}$ treatment under 40 and $100 \mathrm{~mm}$ tension. These figures substantiate the ability of PAM to preserve a more porous pore structure during the formation of surface seals in irrigated furrows. Recognizably, PAM-treated furrows had more unblocked pores with equivalent mean diameter of less than $0.75 \mathrm{~mm}$ at $40 \mathrm{~mm}$ tension or less than $0.30 \mathrm{~mm}$ at $100 \mathrm{~mm}$ tension throughout the experiment, showing the influence of particle size on surface seal conductivity.

Table 5

Average intake rates and cumulative infiltration for four monitored polyacrylamide (PAM) treated and control irrigation periods

\begin{tabular}{|c|c|c|c|c|c|c|}
\hline \multirow[b]{2}{*}{$\begin{array}{l}\text { Monitored } \\
\text { irrigation } \\
\text { period }\end{array}$} & \multicolumn{3}{|c|}{ Infiltration rate } & \multicolumn{3}{|c|}{ Cumulative infiltration } \\
\hline & $\begin{array}{l}\text { Control, } \\
l / m \text { min }\end{array}$ & $\begin{array}{l}\text { PAM- } \\
\text { treated, } \\
l / m \text { min }\end{array}$ & $\begin{array}{c}\text { Increase } \\
\%\end{array}$ & $\begin{array}{c}\text { Control, } \\
l / m\end{array}$ & $\begin{array}{c}\text { PAM- } \\
\text { treated, } \\
l / m\end{array}$ & $\begin{array}{c}\text { Increase } \\
\%\end{array}$ \\
\hline 1 st & $0 \cdot 51$ & 0.59 & $13 \cdot 3$ & $46 \cdot 0$ & $78 \cdot 8$ & $41 \cdot 6$ \\
\hline 2nd & $0 \cdot 27$ & $0 \cdot 34$ & $20 \cdot 5$ & $31 \cdot 9$ & $43 \cdot 8$ & $27 \cdot 2$ \\
\hline $3 \mathrm{rd}$ & $0 \cdot 16$ & $0 \cdot 33$ & $52 \cdot 7$ & $36 \cdot 3$ & $43 \cdot 8$ & $16 \cdot 9$ \\
\hline 4 th & $0 \cdot 11$ & $0 \cdot 24$ & $52 \cdot 7$ & $12 \cdot 8$ & $31 \cdot 8$ & $59 \cdot 7$ \\
\hline
\end{tabular}

Table adapted from data originally presented by Santos et al. (1998). 


\section{Conclusions}

Irrigated Mediterranean soils can greatly benefit from ability of polyacrylamide to influence surface soil conditions, reduce sealing and improve infiltration. The quick sealing of the soil furrow bottom can be prevented, leading to changes in flow management and improved irrigation efficiencies. The increase in cumulative infiltration and hydraulic conductivity will allow for longer irrigation set times and higher inflow rates, enhancing actual management. Current management of the surface irrigation systems, with their short irrigation times and inflow cut backs to minimize runoff losses and increase efficiency, is time-consuming, labour-intensive and non-economical. These shortcomings are often minimized with the use of sophisticated automation systems. Dissolving PAM in irrigation water to a concentration of $10 \mathrm{mg} / \mathrm{l}$ and applying it only during the advance flow until runoff begins, seems to be an effective method to use the product, and a viable alternative option to management. Application during the advance phase will preserve the pervious pore structure of irrigated furrows and ensure that losses of PAM from furrow tail water are minimized and season-long application amounts are reduced.

\section{Acknowledgements}

This work was partially funded through IHERA INTERREG II-C \#98.09.5671.8. The authors would also like to acknowledge Eng. Henrique Fontelonga, Eng. Rodrigo Rodrigues and Mr. Manuel Junça for their dedicated work and technical support in the execution of this study.

\section{References}

Barvenik F W (1994). Polyacrilamide characteristics related to soil applications. Soil Science, 158, 235-243

Ben-Hur M (1994). Runoff, erosion and polymer application in moving-sprinkler irrigation. Soil Science, 158(4), 283-290

Blair A W; Trout T J (1989). Recirculating furrow infiltrometer design guide. Technical report CRWR 223, Center for Research in Water Resources, College of Engineering, University of Texas, Austin

Bondurant J A (1957). Developing a furrow infiltrometer. Agricultural Engineering, 38(8), 602-604

Cook F J; Lilley G P; Nunns R A (1993). Unsaturated hydraulic conductivity and sorptivity: laboratory measurement. In: Soil Sampling and Methods of Analysis (Carter M R ed), pp 615-634. Lewis Publications, Boca Raton, FL

Gardner W R (1958). Some steady-state solutions of the unsaturated moisture flow equation with application to evaporation from a water table. Soil Science, 85, 228-232

Hussen A A; Warrick A W (1993). Algebraic models for disc tension permeameters. Water Resources Research, 29, $2779-2786$
Hussen A A; Warrick A W (1995). Tension infiltrometers for the measurement of vadose zone hydraulic properties. In: Handbook of Vadose Zone Characterisation and Monitoring (Wilson L G; Everett L G; Cullen S J eds), pp 189-201. Lewis Publishers, Boca Raton, FL

Lentz R D; Shainberg I; Sojka R E; Carter D L (1992). Preventing irrigation furrow erosion with small applications of polymers. Soil Science, Society of America, 56, 1926-1932

Lentz R D; Sojka R E (1994). Field results using polyacrylamide to manage furrow erosion and infiltration. Soil Science, 158, 274-282

Lentz R D; Sojka R E (1996). Five year research summary using PAM in furrow irrigation. In: Managing Irrigation-Induced Erosion and Infiltration with Polyacrylamide (Sojka R E; Lentz, R D eds), pp 20-27. University of Idaho Misc. Publication No. 101-96, College of Southern Idaho, Twin Falls

Malano H M (1982). Comparison of the infiltration process under continuous and surge flow. MS Thesis, Utah State University, Logan

McCutchan H; Osterli P; Letey J (1993). Polymers check furrow erosion, help river life. California Agriculture, 47, 10-11

Perroux K M; White I (1988). Design of disc permeameters. Soil Science Society of America Journal, 52, 1205-1215

Raposo J R (1997). A rega: dos primitivos regadios às modernas técnicas de rega [Irrigation: from primitive systems to the modern irrigation techniques.] Fundação C. Gulbenkian, Lisbon

Ross C W; Sojka R E; Lentz R D (1996). Polyacrylamide as a tool for controlling sediment runoff and improving infiltration under furrow irrigation. Proceedings of the Australia and New Zealand National Soils Conference, Vol. 2, pp 229-230. Melbourne, Australia

Santos F L; Serralheiro R P; Melhorado F S; Oliveira M R (1998). Control of furrow erosion and infiltration on a Mediterranean soil using polyacrylamide. In: Water and The Environment: Innovative Issues in Irrigation and Drainage (Pereira L S; Gowing J eds), pp 84-91. E \& FN Spon, London

Segeren A; Trout T (1991). Hydraulic resistance of soil surface seals in irrigated furrows. Soil Science Society of America, $\mathbf{5 5}(3), 640-646$

Serralheiro R P (1995). Furrow irrigation advance and infiltration equations for a Mediterranean soil. Journal of Agricultural Engineering Research, 62, 117-126

Smettem K R J; Clothier B E (1989). Measuring unsaturated sorptivity and hydraulic conductivity using multiple disk permeameters. Journal of Soil Science, 40, 563-568

Sojka R E; Lentz R D (1996). A PAM primer: A brief history of PAM and PAM-related issues. In: Managing Irrigation-Induced Erosion and Infiltration with Polyacrylamide (Sojka R E; Lentz, R D eds), pp 11-19. University of Idaho Misc. Publication No. 101-96, College of Southern Idaho, Twin Falls

Sojka R E; Lentz R D (1997). Reducing furrow irrigation erosion with polyacrylamide (PAM). Journal of Production Agriculture 1997, 10(1), 47-52

Sojka R E; Lentz R D; Ross C W; Trout T J; Bjorneberg D L, Aase J K (1998). Polyacrylamide effects on infiltration in irrigated agriculture. Journal of Soil and Water Conservation, 53(4), 325-331

Testezlaf R; Elliott R L; Garton J E (1987). Furrow infiltration under surge flow irrigation. Transactions of the ASAE, 30(1), 193-197 
Trout T J (1990). Surface seal influence on surge flow furrow infiltration. Transactions of the ASAE, 33(5), 1583-1589

Trout T J; Sojka R E; Lentz R D (1995). Polyacrylamide effect on furrow erosion and infiltration. Transactions of ASAE, 38, 761-765

USDA NRCS (1995). Irrigation erosion control (Polyacrylamide). WNTC Interim 201-1. NRCS West National Technical Center Interim Conservation Practice Standard, U S Government Printing Office, Washington D C

White I; Sully M J (1987). Macroscopic and microscopic capillary length and time scales from field infiltration. Water Resources Research, 28, 427-431

White I; Sully M J; Perroux K M (1992). Measurement of surface-soil hydraulic properties: disc permeameters, tension infiltrometers and other techniques. In: Advances in Measurement of Soil Physical Properties: Bringing Theory Into Practice (Topp G C ed), Soil Science Society of America Special Publication, Vol. 30, pp 69-104. Madison, WI

Wooding R A (1968). Steady infiltration from a shallow circular pond. Water Resources Research, 4, 1259-1273

Zhang X C; Miller W P (1996a). Physical and chemical processes affecting runoff and erosion in furrows. Soil Science Society of America Journal, 60(3), 860-865

Zhang X C; Miller W P (1996b). Polyacrylamide effect on infiltration and erosion in furrow. Soil Science Society of America Journal 1996b, 60(3), 866-872 